\title{
THE MISSING DIMENSION OF KNOWLEDGE TRANSFER FROM SUBSIDIARIES TO HEADQUARTERS: THE CASE OF OIL AND GAS COMPANIES IN CEE REGION
}

\author{
Emil Velinov \\ University of Economics, Prague, Czech Republic \\ Stefan Gueldenberg \\ University of Liechtenstein
}

\begin{abstract}
The paper identifies knowledge management determinants of knowledge transfer from subsidiaries to headquarters in the top Oil \& Gas companies in Central and Eastern Europe as their level of innovations, internationalization and economic importance are emerging. The paper sheds a light not only on the process of knowledge transfer parent-subsidiary but via versa as it is critical in the 21st century for better adapting to specific business needs in certain geographical regions. Thus, this reversed knowledge from subsidiaries to headquarters is critical for the given business sector where the level of innovation and amount of R\&D investments are enormous. The study argues that the reversed process of knowledge transfers from subsidiary to parent company is positively related to company performance and business diversification. Nowadays the knowledge formed in the subsidiaries of Multinational Corporations (MNCs) is transferred to headquarters by investing in R\&D centers, building new exploration and testing sites abroad. In the reversed knowledge transfer process we can identify main challenges, which are very critical to analyze and determine the exact process.
\end{abstract}

Keywords: Reversed knowledge transfer, Subsidiary-parent, Oil and gas companies, Central and Eastern Europe.

DOI: http://dx.doi.org/10.15549/jeecar.v3i2.140

\section{INTRODUCTION}

In recent years Oil \& Gas sector came to attention of governments, financial analysts and economists because of the its strategic role and global importance for the World economy. Moreover, Oil \& Gas business is characterized with high rate of innovations. The paper investigates what is the correlation between knowledge transfer and company performance along with the correlation between knowledge transfer and level of internationalization as main trends in Oil \& Gas sector in the CEE region. The number of multinational companies (MNCs) and the amount of their employees is surging globally. Along with it, the pace and size of foreign direct investments (FDIs) to countries outside the developed world are expanding. The same matter also applies to Central and Eastern Europe, where multinational 
corporations play a very important role in the economy of the region. The contribution of these companies to the Central and Eastern European region is considerable, and they employ more than $25 \%$ of the people working in the private sector. Their human resource decisions have an impact on the practices of other 'drivers' of the economy. It should also be pinpointed that in 2012, the value of FDI in CEE exceeded $30 \%$ of the average GDP for the region. Multinational companies are an important playground for learning (Bonache and Brewster, 2001) and for cross-border knowledge transfer. They also play key roles in knowledge sharing, since mergers and acquisitions provide excellent opportunities for both parent and subsidiary to renew their knowledge base and to add new knowledge to it (Szulanski, 1996). Subsidiaries can possess a strategic role both in the creation and diffusion of strategically important knowledge.

\section{Reversed knowledge transfer}

The majority of studies cover mainly the knowledge transfer from headquarter to subsidiary but not that many studies paid attention to the process of so called reversed knowledge transfer (subsidiary-headquarter). This phenomenon occurs more and more nowadays as the companies try to adapt themselves to the local market conditions and they try to increase competence and expertise through this revered knowledge transfer. Foss and Pedersen (2004) analyze articles related with transfer of knowledge in MNC's, pointing out that this process can be carried out between subsidiaries through international alliances or from parent company to its subsidiaries. Since the relation subsidiaryparent is under-researched and it is more and more common for the MNC's globally we would to dedicate a special attention to this one. Mechanism that organizations have been used in this process are broad and include: strategic decisions, periodical review of subsidiary object, use of expatriates, coordination, empowerment, training, international trips, best practices and cultural changes and systems. Following Foss and Pedersen (2004), we will focus further on most popular mechanisms in academic publications: expatriates, training, international trips and best practices. The present article also focuses on specific aspects of knowledge transfer which were addressed above. The aim is to analyze the specific features of knowledge transfer in international companies situated in the CEE region, precisely in the field of human resources (Gupta and Govindarajan, 2000). This objective is justified by numerous research results (Birkinshaw, 2001) which emphasize the importance of the aspects of knowledge management and learning in the case of multinational organizations. Research on knowledge transfer in MNCs has shown enormous development over the last one and a half decades.

It has been suggested in the knowledge transfer literature that the absorptive capacity of the receiving unit is the most significant determinant of internal knowledge transfer in MNCs (Gupta and Govindarajan, 2000). Subsidiaries differ in their absorptive capacity, and this affects the level of internal knowledge transfer from other MNC units. The literature, however, offers multiple methods to conceptualize and operationalize absorptive capacity, often not capturing the various facets of absorptive capacity. Moreover, little attention has been paid to the question of whether organizations can enhance the knowledge transfer from subsidiary to parent company and development of absorptive capacity.

Clearly, with a few exemptions, the characteristics of knowledge transfer and absorptive capacity have not been treated as endogenous to organizational processes and arrangements (Foss and Pedersen, 2002). Gupta and Govindarajan (2000) observed that the knowledge inflows into a subsidiary are positively associated with the richness of transmission channels, motivation to acquire knowledge, and capacity to absorb incoming knowledge.

Szulanski (1996) studied the impediments to the transfer using a slightly different approach. He applied all sets of factors together in an eclectic model to measure their relative impact on knowledge transfer (internal stickiness). His findings suggest that along with causal ambiguity and relationships between source and recipient units, the recipients' lack of absorptive capacity is the most important impediment to knowledge transfer within the firm. The role of absorptive capacity of the receiving unit also stands out as the most significant determinant of knowledge transfer in a number of other studies (e.g., Lane 
and Lubatkin, 1998; Gupta and Govindarajan, 2000).

\section{Absorptive capacity}

In their seminal work, Cohen and Levinthal (1990) defined absorptive capacity as the 'ability to recognize the value of new external information, assimilate it, and apply it to commercial ends'. Cohen and Levinthal (1990) assumed that a firm's absorptive capacity tends to develop cumulatively, is path dependent and builds on existing knowledge: 'absorptive capacity is more likely to be developed and maintained as a byproduct of routine activity when the knowledge domain that the firm wishes to exploit is closely related to its current knowledge base'.

Headquarters can benefit from their subsidiary knowledge in many ways: Local knowledge can enable headquarters to adjust and coordinate a global strategy, improve processes in their own or other entities in the network, or simply provide the missing link in the quest to develop a new product. It could originate from different knowledge domains, e.g. marketing, sales, procurement or technology. In this paper we take an aggregate view on the reversed knowledge transfer from subsidiaries to headquarters. We define benefit as the overall value of a knowledge transfer as perceived by headquarters and subsidiaries. With this definition, we intend to capture benefit in its most holistic way: through the eyes of the beneficiary of this knowledgeparent company and subsidiary.

\section{METHODOLOGY OF THE RESEARCH}

\section{Dataset}

In the paper are employed data on the biggest twenty-five Oil \& Gas companies in the Central and Eastern Europe according to their turnover, number of employees, performance and geographical scope of work. The secondary data have been collected from Thomson Reuters

One database, LexisNexis, companies' websites and others secondary sources of information.

Also, regression and correlation analyses have been applied in SPSS in order to find the relationship in terms of reversed knowledge transfer from subsidiary to parent company regardless the company ownership and its corporate governance. We will first elaborate on the subsidiaries' geographic location as a potential source of value (Foss \& Pedersen, 2002; Frost, 2001; Solvell \& Zander,1995) before turning to the subsidiaries' own role and strategic position in the MNC network (Ambos, 2002; Gupta \& Govindarajan, 2000; Hansen, 1999; Tsai, 2001). Acknowledging that not every target unit will be able to benefit equally in this process, we introduce the headquarters' absorptive capacity as a final contingency (Cohen \& Levinthal, 1990).

\section{Hypotheses}

In the paper there are formed three hypotheses based on theory Foss and Pederson (2004) and Ambos (2002) on the the HR tools used for knowledge transfer between parent and subsidiary. The hypotheses are the following:

H1: The reversed knowledge transfer from subsidiary to parent company is positively related to company performance.

H2: Higher the level of reversed knowledge from subsidiary to parent company is, higher level of internationalization of the company itself is.

H3: The higher level of subsidiary engagement with parent company is, the higher level of reversed knowledge is.

\section{EXPECTED RESEARCH}

We would like to investigate to what degree subsidiaries actually engaged in reverse knowledge transfers. We are expecting that our results will indicate that almost all subsidiaries engaged at least in some kind of knowledge transfer, although the intensity varied considerably. To obtain a more detailed picture of the reversed knowledge transfer, we computed descriptive statistics of the subsidiaries in order to identify the most important variables and its influence on the knowledge transfer process. It will appear that the occurrence of knowledge flows does by no means equal the benefit generated for the recipient. Especially striking is the fact that headquarters seem to benefit most from the type of knowledge they get least. Marketing know-how is the most frequently transferred knowledge, followed by distribution know-how and technological knowhow. Market data on customers and market data on competitors, in turn, we are expecting to be 
transferred less frequently, but to generate more benefit for the recipient

This research paper tries to analyze theoretical consideration that it is important to investigate the 'benefit from reverse knowledge transfers' instead of focusing on the existence of knowledge flows. Addressing the core issue of this paper, we then turned to estimating the benefits of reverse knowledge transfers for the headquarters and its' subsidiaries.

\section{DISCUSSIONS AND FINDINGS}

Arguably, a striking aspect of our empirical investigation will be that the quantity of knowledge inflows into the headquarters is by no means equal to the benefit. Headquarters in our sample seem to benefit most from what they get least. In general, our descriptive statistics show that the quantity of knowledge flows differs from their respective variables. This supports our reservations about merely measuring intensity to assess knowledge transfer and indicates that research has to consider the value of knowledge transferred.

Probably, the least surprising result is that knowledge within a MNC is primarily transferred from higher developed local knowledge bases to less developed countries. This permits the exploitation of competitive advantages in transition economies. Of our results, the strong impact of the subsidiaries' strategic role is probably most striking. Our data demonstrates that from a headquarters' view, knowledge received from its subsidiaries is very important. In this respect, our results will add to the recent literature on centers of excellence, corporate leaders, and regional innovation centres (Asakawa \& Lehrer,2003; Holm \& Pedersen, 2000; Moore \& Birkinshaw, 1998). As most authors analyze knowledge inflows, not benefits, our results extend the support for these findings on a higher level. Our findings are well in line with such a view, as they show that those units which are deeply integrated in the MNC network, i.e. exhibit high inflows and high outflows, contribute significantly more to headquarters' benefits.

\section{REFERENCES}

Ambos, T. C., Ambos, B., \& Schlegelmilch, B. B. (2006). Learning from foreign subsidiaries: An empirical investigation of headquarters' benefits from reverse knowledge transfers. International Business Review, 15(3), 294312.

Ambos, T. C., \& Ambos, B. (2009). The impact of distance on knowledge transfer effectiveness in multinational corporations. Journal of International Management, 15(1), 1-14.

Ambos, T.C., Ambos, B., Schlegelmilch, B.B., 2006. Learning from the Periphery: An

Empirical Investigation of Headquarters' Benefits from Reverse Knowledge Transfers.

International Business Review 15 (3), 294-312

Bonache, J., \& Brewster, C. (2001). Knowledge transfer and the management of expatriation. Thunderbird International Business Review, 43(1), 145-168.

Birkinshaw, J., \& Hood, N. 1998. Multinational subsidiary evolution: Capability and charter change in foreign-owned subsidiary companies. Academy of Management Review, 23(4): 773-795.

Cohen, W. M., \& Levinthal, D. A. (1990). Absorptive capacity: A new perspective on learning and innovation. Administrative science quarterly, 128-152.

Foss, N. J., \& Pedersen, T. (2002). Transferring knowledge in MNCs: The role of sources of subsidiary knowledge and organizational context. Journal of International Management, 8(1), 49-67.

Foss, N. J., \& Pedersen, T. (2004). Organizing knowledge processes in the multinational corporation: An introduction. Journal of International Business Studies, 35(5), 340 349.

Berchtold, S., Pircher, R., \& Stadler, C. (2010). Global integration versus local adaptation: a case study of Austrian MNCs in Eastern Europe. European Journal of International Management, 4(5), 524-549.

Gupta, A. K., \& Govindarajan, V. (2000). Knowledge flows within multinational corporations. Strategic management journal, 21(4), 473496. 
Szulanski, G. (1996). Exploring internal stickiness: Impediments to the transfer of best practice within the firm. Strategic management journal, 17(S2), 27-43.

Szulanski, G., \& Jensen, R. J. (2006). Presumptive adaptation and the effectiveness of knowledge transfer. Strategic Management Journal, 27(10), 937-957.

Tsai, W. (2001). Knowledge transfer in intraorganizational networks: Effects of network position and absorptive capacity on business unit innovation and performance. Academy of management journal, 44(5), 9961004.

\section{ABOUT THE AUTHORS}

Emil Velinov, email: emil.velinov@vse.cz

Dr. Emil Velinov is an Assistant professor at the Department of Management at Faculty of Business Administration. He has completed his PhD studies at the latter institution in the area of International Management and Business. His international experience is related to managing interinstitutional projects in the area of Diversity Management, New Public Management and International Business. Dr. Velinov has been teaching in several universities across Europe including University of Economics and Business, Vienna, University of Liechtenstein, University of EconomicsPlekhanov, etc. He speaks fluently English, Czech, Bulgarian and Russian and he presents different research papers at international conferences in the area International Management, Diversity Management and Corporate Governance.

Dr. Stefan Gueldenberg from the University of Liechtenstein has quite broad academic experience including Visiting Researcher at the Sloan School of Management, Massachusetts Institute of Technology (MIT) and at the John F. Kennedy School of Government, Harvard University (Schumpeter visiting professorship). At the moment he is a Chair of Management and member of the Senate at the University of Liechtenstein. He is in charge of Teachings in the undergraduate and graduate studies as well as in the continuing education, Involvement in research projects, Execution of knowledge and technology transfer-projects. 


\section{Attachment 1:}

Table 1: List of Oil \& Gas companies with subsidiaries in Central and Eastern Europe

\begin{tabular}{|c|c|c|}
\hline Company Name & Subsidiaries' Locations & HQ's Location \\
\hline Lukoil & Bulgaria, Romania & Russia \\
\hline MOL & $\begin{array}{l}\text { Czech Republic, Slovakia, } \\
\text { Poland }\end{array}$ & Hungary \\
\hline Gazprom & $\begin{array}{l}\text { A ustria, Bulgaria, Czech } \\
\text { Republic, Poland }\end{array}$ & Russia \\
\hline PKN Orlen & Czech Republic, Slovakia & Poland \\
\hline Ceska rafinerska & Slovakia & Czech Republic \\
\hline Unipetrol & Hungary & Czech Republic \\
\hline Slovnaft & Hungary & Slovakia \\
\hline Bulgargaz & Turkey & Bulgaria \\
\hline Petrol Group & $\begin{array}{l}\text { Serbia, Croatia, Bosna \& } \\
\text { Herzegovina }\end{array}$ & Slovenia \\
\hline Eesti Energie & Latvia, Lithuania, Sweden & Estonia \\
\hline Rosneft & Poland & Russia \\
\hline ExxonMobil & Austria & US \\
\hline SOCAR & Romania & Azerbaijan \\
\hline Latvijas Gaze & Lithuania & Latvia \\
\hline OKTA & Macedonia & Greece \\
\hline Adria & $\begin{array}{l}\text { Serbia, Bosna \& } \\
\text { Herzegovina }\end{array}$ & Croatia \\
\hline OMV & $\begin{array}{l}\text { Bulgaria, Czech Republic, } \\
\text { Hungary }\end{array}$ & Austria \\
\hline GDF Suez Gas vertrieb & Austria & France \\
\hline RWE Supply \& Trading & Czech Republic & Germany \\
\hline Eni & Slovakia & Italy \\
\hline TOTAL & Russia & France \\
\hline Statoil & Sweden, Finland & Norway \\
\hline PGE Capital Group & Slovakia & Poland \\
\hline Royal Dutch Shell & Poland, Russia & Netherlands \\
\hline British Petroleum & Austria & UK \\
\hline
\end{tabular}

$\mathrm{N}=25$ 
A ttachment 2:

Table 2: Descriptive statistics

\begin{tabular}{lrrrr}
\hline Variable & M eans & Std.Dev. M in & Max \\
\hline Subsidiary age & 9 & 5,40 & 4 & 22 \\
Subsidiary size & 6 & 5,51 & 0,5 & 30 \\
Subsidiary Performance & 6 & 5,53 & 1 & 40 \\
Subsidiary In vestm ent in R \& & 1 & & & 30 \\
& 0 & 5,56 & 0,5 & \\
N of employees in the subsidiary & 1 & & & 45 \\
Subsidiary In te rnationalization & 2 & 14,10 & 1 & 22 \\
Subsidiary engagement & 1 & 5,92 & 0,1 & 4 \\
\hline
\end{tabular}

